\title{
Antibacterial activity of an endophytic fungus Lasiodiplodia pseudotheobromae IBRL OS-64 residing in leaves of a medicinal herb, Ocimum sanctum Linn.
}

\author{
Taufiq M.M.J.*, Darah I. \\ Industrial Biotechnology Research Laboratory, School of Biological Sciences, Universiti Sains Malaysia, 11800, Penang, Malaysia
}

\begin{tabular}{l}
\hline ARTICLE INFO \\
\hline Article history: \\
Received on: April 25, 2018 \\
Accepted on: July 04, 2018 \\
Available online: January 24, 2019 \\
\hline
\end{tabular}

\section{Key words:}

Antibacterial activity, Endophytic fungus,

Lasiodiplodia pseudotheobromae,

Ocimum sanctum Linn

\begin{abstract}
The study was carried out to investigate the antibacterial activity of an endophytic fungal isolate, Lasiodiplodia pseudotheobromae IBRL OS-64 residing in leaves of a medicinal herb, Ocimum sanctum Linn. Qualitative screening of the antimicrobial activity was done using an agar plug assay, and the results showed that the fungal isolate was able to inhibit all the 13 test bacteria. Three Gram-positive bacteria (methicillin-resistant Staphylococcus aureus [MRSA] ATCC 33591, Staphylococcus aureus, and Streptococcus mutans) were the most susceptible species with the inhibition zones of $\geq 21 \mathrm{~mm}$. The other three (Bacillus cereus ATCC 10876, Bacillus subtilis IBRL A3, and Streptococcus agalactiae) showed the inhibition zones of $11-\leq 20 \mathrm{~mm}$ of diameter. As for Gram-negative bacteria, Yersinia enterocolitica was the most susceptible to the fungal isolate with the size of inhibition zone of $\geq 21 \mathrm{~mm}$, followed by Klebsiella pneumoniae ATCC 13883, Salmonella typhimurium, and Shigella boydii ATCC 9207 with the inhibition zones of 11- $\leq 20 \mathrm{~mm}$, whereas Escherichia coli IBRL 0157, Proteus mirabilis, and Pseudomonas aeruginosa ATCC 27883 were the least susceptible with the inhibition zones of $\leq 10 \mathrm{~mm}$. Quantitative screening using disc diffusion assay showed that the fungal ethyl acetate extract prepared from the fermentative broth (extracellular) exhibited better antibacterial activity compared to the methanolic extract prepared from the fungal biomass (intracellular). The results showed that the ethyl acetate extract exhibited antibacterial activity against all the 13 test bacteria with the inhibition zone sizes of $20.0 \pm 0.3-31.3 \pm 1.2 \mathrm{~mm}$ in diameter for Gram-positive bacteria and $10.31 \pm 0.6-20.1 \pm 0.6 \mathrm{~mm}$ in diameter for Gram-negative bacteria. On the other hand, the methanolic extract only inhibited three Gram-positive bacteria (MRSA ATCC 33591, S. aureus, and S. mutans) with the inhibition zones of $9.0 \pm 0.6-11.0 \pm 0.3 \mathrm{~mm}$ in diameter, whereas only one Gram-negative (S. typhimurium) with the inhibition zone size of $13.3 \pm 1.5 \mathrm{~mm}$ diameter. The minimal inhibitory concentration (MIC) and minimum bactericidal concentration $(\mathrm{MBC})$ values of the ethyl acetate extract on Gram-positive bacteria were in the range of 62.50-125.00 and 62.50$500.00 \mu \mathrm{g} / \mathrm{mL}$, respectively, whereas for the Gram-negative bacteria, the MIC and MBC values were 125.00-250.00 and $250.0-1000.00 \mu \mathrm{g} / \mathrm{mL}$, respectively. On the other hand, the MIC and $\mathrm{MBC}$ values for methanolic extract against Gram-positive bacteria were $250.00-500.00 \mu \mathrm{g} / \mathrm{mL}$ and against Gram-negative bacteria were $1000.00 \mu \mathrm{g} / \mathrm{mL}$, respectively. Both of the extracts exhibited bactericidal effects on test bacteria with the $\mathrm{MBC} / \mathrm{MIC}$ ratio $\leq 4$. Further, detail of the effects of the ethyl acetate extract on the bacterial cells was observed from the scanning electron microscopy photomicrographs which revealed the severity of the morphological deterioration experienced by the extract-treated cells were beyond repair, and the most possible mode of actions were by interrupting the cell wall biosynthesis and cell membrane permeability.
\end{abstract}

\section{INTRODUCTION}

The problems of bacterial resistance strains are increasing, and the outlook for the use of the existing antibiotics against human pathogenic microbes has prompted an intensive search for newer and more effective antibiotics [1]. Therefore, actions must be taken to reduce this problem by controlling the overuse of antibiotics and to continue

*Corresponding Author:

Taufiq M.M.J., Universiti Sains Malaysia, Penang, Malaysia.

E-mail: fiqz04@yahoo.com.sg searching for new save drugs, either synthetic or natural. The ultimate goal is to offer appropriate and efficient antibiotics to the patients. Infections caused by bacterial pathogens such as methicillin-resistant Staphylococcus aureus (MRSA), vancomycin-resistant enterococci, and many more [2,3] remain a growing health risk globally [4], and identification of new molecules active against these pathogenic bacteria is highly desired.

Endophytic fungi have been known to be the reservoir of many useful bioactive compounds [5]. They are special group of microorganisms residing within the plant tissues, which play an important role 
in defending the host plant against stresses such as pathogenic invasions and drought. Furthermore, they are colonizing the internal or external parts of healthy plants tissue asymptotically and most of the plants that have been previously studied become host at least for one endophyte [6]. In fact, endophytic fungi are generally nonpathogenic in nature but may produce secondary metabolites that enable them to survive in the competitive world of plant interstitial space without harming their host. Endophytic fungi have evolved tremendously with their host plants, and they are able to produce arrays of diverse secondary metabolites with various functions [5] such as antimicrobial [7], antibacterial [8,9], antifungal [10,11], anticancer [12,13], anti-inflammatory [14], antiviral [15], and antioxidant activities [16]. Thus, studies on endophytic fungi become more popular amongst researchers.

Lasiodiplodia pseudotheobromae is better known as a common fungal pathogen that causes diseases on large number of hosts plants in the tropics and subtropics such as on mango which causes dieback disease [17,18], which can cause trunk cankers in Acacia mangium in Venezuela [19], postharvest fruit rot of lemon in Turkey [20], and persimmon rot in Brazil [21]. However, recently, it has been known as an endophytic fungus which residing in various parts of host plants and has been reported to exhibit various pharmaceutical activities such antibacterial [22,23], xanthine oxidase inhibitory [24], fibrinolytic [25], and anticancer [26] activities. In fact, Qian et al. [27] reported the ability of Lasiodiplodia sp. ME4-2, an endophytic fungus from the floral parts of Viscum coloratum, to produce indole-3-carboxylic acid and other aromatic metabolites.

In general, the study on antimicrobial activity of L. pseudotheobromae is scarce and thus the current study is planning to investigate the antibacterial activity of L. pseudotheobromae IBRL OS-64 against various test bacteria. The study is very important and significant since this is the first report of L. pseudotheobromae isolated from Ocimum sanctum Linn. leaves.

\section{MATERIALS AND METHODS}

\subsection{Endophytic Fungus, Culture, and Maintenance}

The endophytic fungus previously isolated from leaf of $O$. sanctum Linn. was provided by the culture collection of the Industrial Biotechnology Research Laboratory (IBRL), Universiti Sains Malaysia, Penang, Malaysia. The fungal isolate was cultured and maintained on potato dextrose agar (PDA) supplemented with powdered host plant $(2 \mathrm{~g} / \mathrm{L})$ and incubated at $30^{\circ} \mathrm{C}$ aerobically for 7 days before storing it at $4^{\circ} \mathrm{C}$ before use. The isolate was subcultured on sterile fresh medium once a month to ensure its purity and viability.

\subsection{Culture Medium}

Yeast extract sucrose broth (YES; Merck, Germany) [9] which contained (g/L) yeast extract, 20; sucrose, 40; and magnesium sulfate, 0.5 was added into $1000 \mathrm{~mL}$ distilled water supplemented with $O$. sanctum leaf water extract. The host plant extract was prepared by boiling $1.0 \mathrm{~g}$ of the powdered leaf in $500 \mathrm{~mL}$ distilled water for $30 \mathrm{~min}$. The mixture was then filtered through Whatman filter paper, and the filtrate was mixed with freshly prepared culture medium, followed by autoclaving at $121^{\circ} \mathrm{C}$ for $15 \mathrm{~min}$. The medium was used to cultivate the endophytic fungal isolate in a shake-flask system. The $\mathrm{pH}$ of the culture medium was adjusted to 5.8 .

\subsection{Cultivation and Extraction}

The inoculum was prepared by introducing two mycelial agar plugs approximately $1.0 \mathrm{~cm}$ in diameter and $4.0 \mathrm{~mm}$ thickness, which were excised from the periphery of 7-day-old endophytic fungal cultures into $250 \mathrm{ml}$ Erlenmeyer flasks containing $100 \mathrm{~mL}$ of YES broth medium. The cultures were cultivated at $30^{\circ} \mathrm{C}$ with agitation speed of $120 \mathrm{rpm}$ for 20 days in the dark. After the incubation period, the fermented broth and fungal biomass were separated out using Whatman No. 1 filter papers. The fungal biomass was washing twice using sterile distilled water and freeze-dried before macerating in methanol $(1: 50, \mathrm{w} / \mathrm{v})$ overnight. The macerated mixture was filtered using muslin cloth and followed by Whatman no. 1 filter paper to separate the biomass filtrate from the biomass residue. The fungal biomass filtrate was then concentrated to dryness under reduced pressure in a rotary evaporator to obtain a methanolic crude extract paste. On the other hand, the filtered fermented broth was extracted thrice with equal volume of ethyl acetate $(1: 1, \mathrm{v} / \mathrm{v})$. The upper organic phase was collected and subsequently was concentrated to dryness under reduced pressure in a rotary evaporator to obtain an ethyl acetate crude extract paste. A control was included by extracting the sterile medium following exactly the same steps as that for fungal cultures due to antimicrobial activities exhibited by $O$. sanctum Linn. extract.

\subsection{Test Microorganisms and Culture Maintenance}

A total of 13 test bacteria provided by IBRL, Universiti Sains Malaysia, Penang, Malaysia, were used in this study including six Gram-positive bacteria (Bacillus cereus ATCC 10876, Bacillus subtilis IBRL A3, MRSA ATCC 33591, S. aureus, Streptococcus mutans, and Streptococcus agalactiae) and seven Gram-negative bacteria (Klebsiella pneumoniae ATCC 13883, Shigella boydii ATCC 9207, Escherichia coli IBRL 0157, Salmonella typhimurium, Pseudomonas aeruginosa ATCC 27844, Yersinia enterocolitica, and Proteus mirabilis). The inoculum of bacteria was prepared by transferring 3-4 single pure colonies into $5.0 \mathrm{~mL}$ of $0.85 \%$ sterile physiological saline $(\mathrm{w} / \mathrm{v})$ and mixing well to obtain cell suspension. The turbidity of the bacterial suspension was adjusted to match 0.5 McFarland standard (approximately $1 \times 10^{8} \mathrm{CFU} / \mathrm{mL}$ ). To obtain the desirable inoculum size as required by CSLI [28], further, dilution with $0.85 \%(\mathrm{w} / \mathrm{v})$ sterile physiological saline was conducted. The cultures were maintained on nutrient agar and the inoculated plates were incubated at $37^{\circ} \mathrm{C}, 24 \mathrm{~h}$ before storing them at $4^{\circ} \mathrm{C}$ until used. The cultures were subculture every month on fresh nutrient agar slants to ensure its viability.

\subsection{Agar Plug Diffusion Assay}

Primary screening of antimicrobial activity of the endophytic fungal isolates was carried out by adopting the modified agar plug method described previously by Mohanraj et al. [29]. The isolated endophytic fungal cultures were inoculated onto PDA plates containing host plant powder $(2 \mathrm{~g} / \mathrm{L})$ and incubated at $25^{\circ} \mathrm{C}$ for 20 days before cutting them using a sterile cork borer into agar plugs of $1.0 \mathrm{~cm}$ diameter and $4.0 \mathrm{~mm}$ thickness. The agar plugs were then placed on the Mueller-Hinton agar (MHA) seeded with test bacteria, and the plates were initially kept overnight at $4{ }^{\circ} \mathrm{C}$ to allow diffusion of bioactive compounds and subsequently incubated at $37^{\circ} \mathrm{C}$ for $24 \mathrm{~h}$. Chloramphenicol $(30 \mu \mathrm{g} / \mathrm{mL})$ was used as a positive control and the inhibition zone formed around the endophyte agar plugs were measured. The experiments were carried out in triplicate and the results were expressed as mean value \pm standard error of the inhibition zone obtained from three separated experiments. Endophytic fungal isolates exhibiting significant antibacterial activity against test bacteria were subjected to secondary screening. 


\subsection{Disc Diffusion Susceptibility Assay}

The assay was carried out according to the method as previously described by Clinical and Laboratory Standard Institute (CLSI) standard M100-S16 (CLSI, 2006) [30] and M100-S22 [31]. The inocula were prepared by transferring 3-4 single colonies into $5.0 \mathrm{~mL}$ of sterile physiological saline and mixing well to obtain cell suspensions of approximately $1 \times 10^{8} \mathrm{CFU} / \mathrm{mL}$, by comparison with $0.5 \mathrm{McF}$ arland standards. The test bacteria were seeded on MHA using a sterile swab with spread plate technique.

The fungal crude extracts were prepared by dissolving $10.0 \mathrm{mg}$ of extract in $0.2 \mathrm{~mL}$ of $5 \%$ dimethyl sulfoxide (DMSO) and subsequently added with $0.8 \mathrm{~mL}$ of sterile distilled water to get a concentration of $1 \mathrm{mg} / \mathrm{mL}$. The sterile $6.0 \mathrm{~mm}$ diameter of antibiotic discs was impregnated with $20 \mu \mathrm{L}$ of the extract and air-dried before placing them on the Mueller-Hinton seeded agar surface. Chloramphenicol at the concentration of $30 \mu \mathrm{g} / \mathrm{mL}$ was used as a positive control and $1.0 \%$ of DMSO as a negative control. The inhibition zone formed around the endophyte agar plugs were measured after incubation for $24 \mathrm{~h}$. The experiments were carried out in triplicate, and the results were expressed as mean value \pm standard error of the inhibition zone obtained from three separated experiments.

\subsection{MIC and MBC Determinations}

The MIC of the fungal ethyl acetate crude extract against test bacteria was determined by broth microdilution assay as described by Jorgensen and Ferraro [32] with some modifications. Only test microorganisms that showed significant inhibitory activity on disc diffusion assay were proceeded and evaluated using sterile 96 wells, U-shaped microtiter plate. A single-fold dilution of the fungal extract was prepared in sterile Mueller-Hinton broth (MHB) medium and 100 $\mu \mathrm{L}$ of the extract was dispensed into each well of the microtiter plate. Then, $100 \mu \mathrm{L}$ of test microorganisms' inocula at approximately $1 \times$ $10^{7} \mathrm{CFU} / \mathrm{mL}$ was added into each well for a final volume of $200 \mu \mathrm{L}$, and the final concentration of microbial inocula in each well was $1 \times$ $10^{7} \mathrm{CFU} / \mathrm{mL}$. Chloramphenicol was used as a reference drug. The $5 \%$ methanol and bacterial inoculum were included as control. After $24 \mathrm{~h}$ of incubation period at $37^{\circ} \mathrm{C}, 40 \mu \mathrm{L}$ of $0.2 \mathrm{mg} / \mathrm{ml} \mathrm{p}$-iodonitrotetrazolium violet (INT) dissolved in $99.5 \%$ ethanol was loaded to each well as a growth indicator. The MIC value was determined and recorded as the lowest concentration of the ethyl acetate crude extract that capable to inhibit the visible growth of test microorganisms after the incubation period [33].

The MBC of the fungal ethyl acetate crude extract was subsequently determined on reading of the MIC values. The viable cells from wells that showed no microbial growth were enumerated on MHA by a standard viable plate count after $24 \mathrm{~h}$ of incubation period at $37^{\circ} \mathrm{C}$ for overnight. The MBC was observed and recorded as the lowest concentration of fungal ethyl acetate crude extract that resulted in reduction of $99.9 \%$ bacterial growth relative to the growth control [34].

\subsection{Scanning Electron Microscopy (SEM)}

For sample preparation, $50 \mu \mathrm{L}$ of bacterial inoculum (approximately $1 \times 10^{8} \mathrm{CFU} / \mathrm{mL}$ ) was transferred into a $25 \mathrm{~mL}$ Erlenmeyer flask containing $945 \mu \mathrm{L}$ of MHB and incubated in an orbital shaker at $37^{\circ} \mathrm{C}, 150 \mathrm{rpm}$ for $18-20 \mathrm{~h}$. A volume of $0.5 \mathrm{~mL}$ of ethyl acetate crude extract $(5 \mathrm{mg} / \mathrm{mL})$ was added into the bacterial culture after incubation period to yield a volume of $10 \mathrm{~mL}$ mixture with extract concentration of $0.5 \mathrm{mg} / \mathrm{mL}$. At the meantime, $0.5 \mathrm{~mL}$ of $20 \%$ DMSO (v/v) was added into bacterial culture as a replacement to the extract and served as control. The mixture was then incubated at $37^{\circ} \mathrm{C}, 150 \mathrm{rpm}$ for $36 \mathrm{~h}$. The cultures were harvested at 0 and $36 \mathrm{~h}$ of incubation period and proceed for SEM works as described previously by Borges et al. [35]. The prepared samples were then viewed under SEM (Leica Cambridge, S-360, UK).

\subsection{Statistical Analysis}

The data obtained in this study were analyzed by Students' $t$-test for comparing the effect of ethyl acetate extract on test microorganism cells against control using the SPSS Version 12.0. All tests were independently performed in triplicates. The results obtained were analyzed using a one-way ANOVA test and reported as the mean \pm standard deviation.

\section{RESULTS}

\subsection{Qualitative Screening for Antibacterial Activity}

The endophytic fungus, L. pseudotheobromae IBRL OS-64, was primarily screened using agar plug diffusion assay to detect the existing of antibacterial activity against test microorganisms [Table 1]. The extract exhibited antibacterial activity against all the 13 bacterial species tested. Three Gram-positive bacteria (MRSA ATCC 33591, $S$. aureus, and $S$. mutans) were the most susceptible species with the inhibition zones of $\geq 21 \mathrm{~mm}$. The other three (B. cereus ATCC 10876, B. subtilis IBRL A3, and S. agalactiae) showed the inhibition zones of $11-\leq 20 \mathrm{~mm}$ of diameter. As for Gram-negative bacteria, $Y$. enterocolitica was the most susceptible to the fungal endophytes isolate with the size of inhibition zone of $\geq 21 \mathrm{~mm}$, followed by K. pneumoniae ATCC 13883, S. typhimurium, and S. boydii ATCC 9207 with the inhibition zones of $11-\leq 20 \mathrm{~mm}$, whereas E. coli IBRL 0157 , $P$. mirabilis, and P. aeruginosa ATCC 27844 were the least susceptible with the inhibition zones of $\leq 10 \mathrm{~mm}$. The results obtained showed that L. pseudotheobromae IBRL OS-64 possessed prominent antibacterial

Table 1: Primary screening of antibacterial activity of Lasiodiplodia pseudotheobromae IBRL OS-64 against test microorganisms using agar plug diffusion assay

\begin{tabular}{lc} 
Test bacteria & $\begin{array}{c}\text { Inhibition } \\
\text { zones }\end{array}$ \\
Gram-positive bacteria & ++ \\
Bacillus cereus ATCC 10876 & ++ \\
Bacillus subtilis IBRL A3 & +++ \\
Methicillin-resistant Staphylococcus aureus ATCC & \\
33591 & +++ \\
Staphylococcus aureus & +++ \\
Streptococcus mutans & ++ \\
Streptococcus agalactiae & \\
Gram-negative bacteria & + \\
Escherichia coli IBRL 0157 & ++ \\
Klebsiella pneumoniae ATCC 13883 & + \\
Proteus mirabilis & + \\
Pseudomonas aeruginosa ATCC 27844 & ++ \\
Salmonella typhimurium & ++ \\
Shigella boydii ATCC 9207 & ++ \\
Yersinia enterocolitica & + \\
\hline
\end{tabular}

$+=$ Inhibition zone $\leq 10 \mathrm{~mm},++=$ Inhibition zone 11 to $\leq 20 \mathrm{~mm},+++=$ Inhibition zone $\geq 21 \mathrm{~mm}$ 
activity against test bacteria which comprised pathogenic bacteria to human. The results also revealed that Gram-positive bacteria were more susceptible to the extract compared to Gram-negative bacteria.

\subsection{Disc Diffusion Assay}

The antibacterial activity of L. pseudotheobromae IBRL OS-64 extracts was determined using disc diffusion assays and the results are shown in Table 2. In general, the ethyl acetate extract prepared from the fermentative broth (extracellular) exhibited better antimicrobial activity compared to the methanolic extract prepared from the fungal biomass (intracellular). The results showed that the ethyl acetate extract exhibited antibacterial activity against all the 13 test bacteria with the inhibition zone sizes of $20.0 \pm 0.3-31.3 \pm 1.2 \mathrm{~mm}$ diameter for Gram-positive bacteria and 10.31 $\pm 0.6-20.1 \pm 0.6 \mathrm{~mm}$ diameter for Gram-negative bacteria. On the other hand, the methanolic extract only inhibited three Gram-positive bacteria (MRSA ATCC 33591, S. aureus, and $S$. mutans) with the inhibition zones of 9.0 $\pm 0.6-11.0 \pm$ $0.3 \mathrm{~mm}$ diameter, whereas only one Gram-negative (S. typhimurium) with the inhibition zone size of $13.3 \pm 1.5 \mathrm{~mm}$ diameter.

The results obtained from this study indicated that the antibacterial compounds were mainly not associated with the fungal biomass but extracellularly released by the fungus into the fermentative broth. The extracellular compound might be an advantage to obtain higher extraction yield since the intracellular compound needs a proper disruption of the fungal mycelial to release and gain higher yield of the compounds [9]. Table 2 also revealed that the ethyl acetate extract of the fermentative broth showed a good antimicrobial activity against Gram-positive compared to Gram-negative bacteria, indicating that Gram-positive bacteria were more susceptible to the extract. These could be due to the differences in the cell morphology and structures between the two groups of bacteria.

\subsection{MIC and MBC Determinations}

In $\mathrm{MIC}$ and $\mathrm{MBC}$ determinations, it is not appropriate to use the disk diffusion method, as it is impossible to quantify the amount of the antimicrobial agent diffused into the agar medium. Therefore, microdilution method is the most appropriate ones for the determination of MIC values since they offer the possibility to estimate the concentration of the tested antimicrobial agent in the broth medium (microdilution). Either broth or agar dilution method may be used to quantitatively measure the in vitro antimicrobial activity against bacteria and fungi. MIC value recorded is defined as the lowest concentration of the assayed antimicrobial agent that inhibits the visible growth of the microorganism tested, and it is usually expressed in $\mathrm{mg} / \mathrm{mL}$.

The results showed that the Gram-positive bacteria were more susceptible to both of the extracts, ethyl acetate and methanolic extracts, with the MIC values ranged between 31.25 and $125.00 \mu \mathrm{g} / \mathrm{mL}$ and 250.00 and $1000.00 \mu \mathrm{g} / \mathrm{mL}$, respectively [Table 3]. However, Gram-negative bacteria were slightly resisted to both of the extracts, ethyl acetate with the MIC ranged between 125.00 and $250.00 \mu \mathrm{g} / \mathrm{mL}$ and methanolic extract with the MIC value of $1000.00 \mu \mathrm{g} / \mathrm{mL}$. Again, the ethyl acetate extract showed superior antibacterial activity compared to the fungal biomass extract (methanolic extract). The MBC values were also determined and the MBC values of the ethyl acetate extract against the six Gram-positive bacteria were in the range of $62.50-500.00 \mu \mathrm{g} / \mathrm{mL}$. In the meantime, the $\mathrm{MBC}$ values of the ethyl acetate extract against the seven Gram-negative bacteria were in the range of $250.00-1000.00 \mu \mathrm{g} / \mathrm{mL}$. The $\mathrm{MBC}$ values of the methanolic extract against Gram-positive and Gram-negative bacteria were $250.00-1000.00 \mu \mathrm{g} / \mathrm{mL}$ and $1000.00 \mu \mathrm{g} / \mathrm{mL}$, respectively. Both of the extracts exhibited bactericidal effects on test bacteria with the $\mathrm{MBC} / \mathrm{MIC}$ ratio $\leq 4$.

\subsection{Structural Degeneration and Morphological Changes of the Extract-treated Cells}

Further, detail of the effects of the ethyl acetate extract on the bacterial cells was observed from the SEM photomicrographs which revealed the severity of the morphological deterioration experienced by the extracttreated cells was beyond repair, Figure 1 shows the photomicrographs of the ethyl acetate extract on the untreated (control) and extracttreated MRSA ATCC 33591 cells, a Gram-positive bacteria. Figure 1a

Table 2: Antibacterial activity of Lasiodiplodia pseudotheobromae IBRL OS-64 ethyl acetate (extracellular) and methanolic (intracellular) extracts against test microorganisms using disc diffusion assay

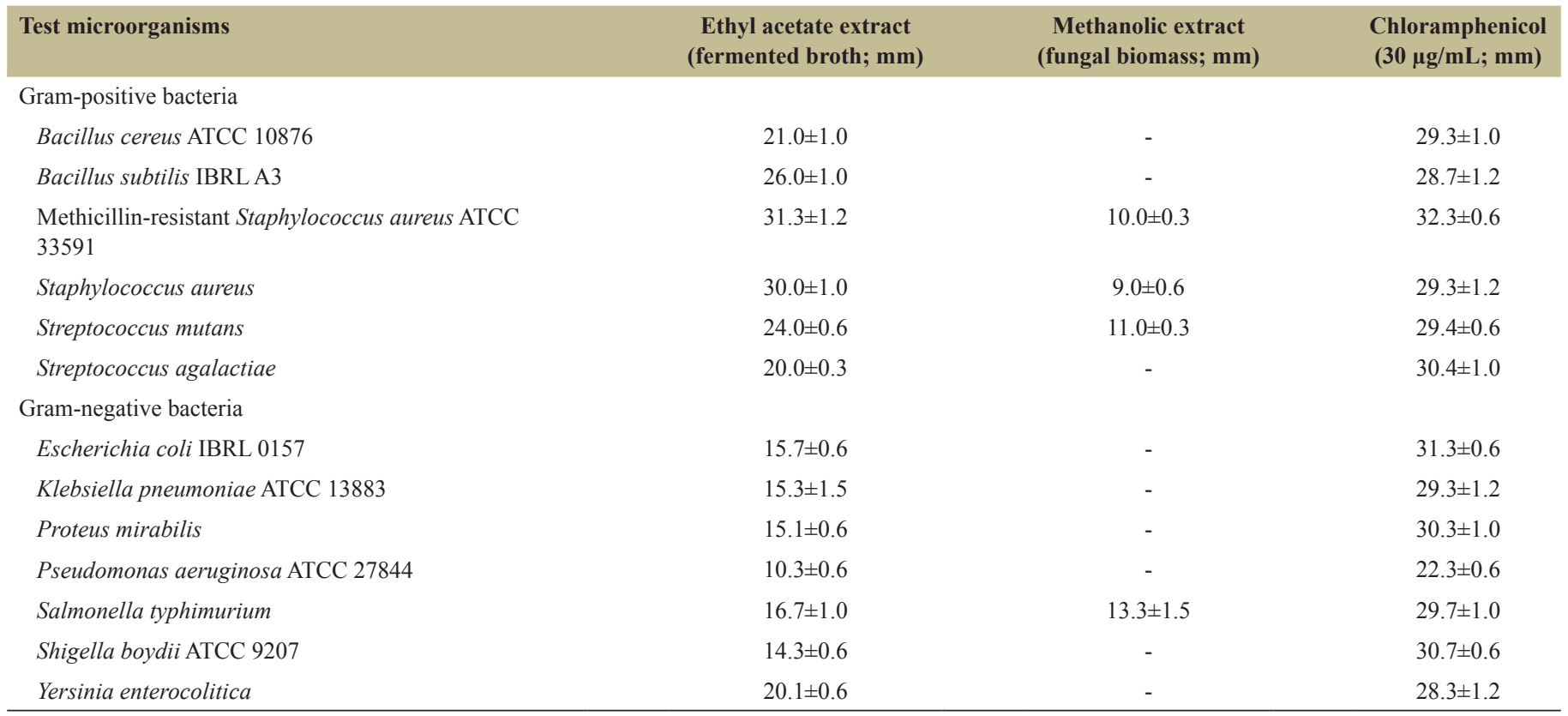


is the untreated cell of MRSA ATCC 33591, which shows the cells with the presence of regular Gram-positive bacterial cells, undamaged and smooth surface with intact spherical shape. The cells were also observed growing actively. However, after $36 \mathrm{~h}$ of treatment with the extract (Figure-1b), the cells become irregular in shape and some of the cells were shrunken cavitized and crumpled losing their coccal or spherical shape. In fact, some of the cells undergone binary fission but cannot completely separate from their mother cells. Severe damage of the cell morphologies were observed as the cells envelope (cell wall) was broken and resulted in leakage of cytoplasm. The lysed cell walls were extremely devoid of cytoplasmic contents which led to completely collapsed and left only the homologous cell masses (or cells debris). Eventually, the cell death completely occurred.

Figure 2 revealed the effects of the ethyl acetate extract on the P. aeruginosa ATCC 27844, a Gram-negative bacterial cells. Figure 2a shows the control or untreated cells with the rod shape bacteria with smooth surface. Some of the cells undergo binary fission. On the other hand, after $36 \mathrm{~h}$ of exposure to the extract (Figure 2b), remarkable morphological and distinct feature changes of the cells occurred where there were invaginations and cavitation formed on the cells surfaces and shrunken cells were also observed. The most possible mode of actions of the ethyl acetate extract were by interrupting the cell wall biosynthesis and cell membrane permeability. The results showed that the cells had undergone severe morphological changed and cytological alterations. These damaged cells were lost their metabolic functions and the damage was beyond repair.

\section{DISCUSSION}

The development of resistance by the existing pathogenic bacteria to commercial drugs is a serious problem faced by health services and has become the main concern around the world. This scenario

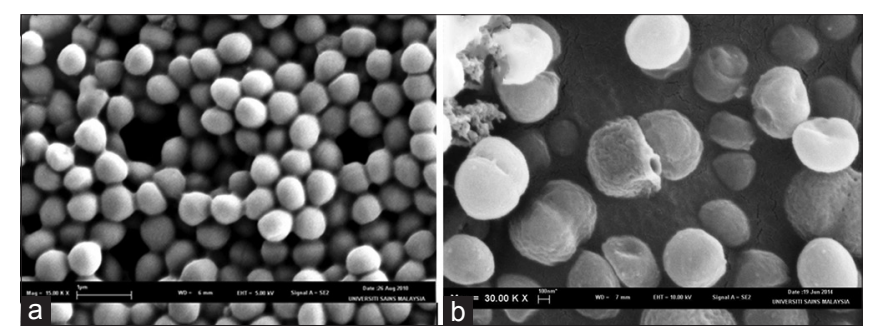

Figure 1: Scanning electron microscopy photomicrographs showing the effects of Lasiodiplodia pseudotheobromae IBRL OS-64 ethyl acetate extract at the concentration of $1.0 \mathrm{mg} / \mathrm{mL}$ on methicillin-resistant Staphylococcus aureus ATCC 33591 cells, (a) untreated cell (control) and (b) extract-treated cell $(\times 5000)$

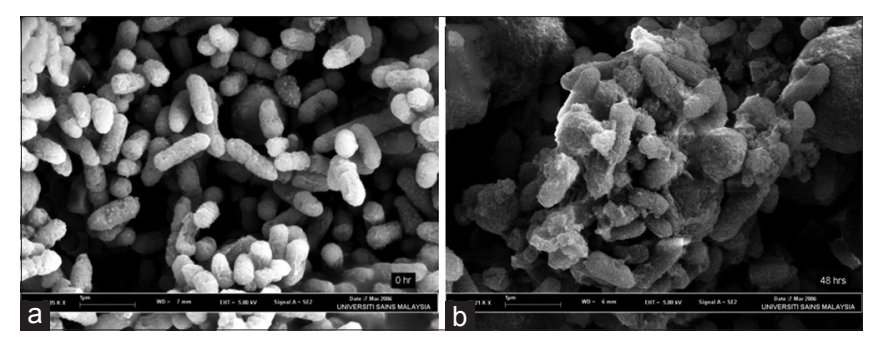

Figure 2: Scanning electron microscopy photomicrographs showing the effects of Lasiodiplodia pseudotheobromae IBRL OS-64 ethyl acetate extract at the concentration of $1.0 \mathrm{mg} / \mathrm{mL}$ on Pseudomonas aeruginosa ATCC 27844 cells, (a) untreated cell (control) and (b) extract-treated cell $(\times 5000)$ involves many factors such as extensive and often inappropriate use of antibiotics, poor hygienic conditions, continuous movement of travelers, increased numbers of immune-compromised patients, and delay in diagnosis of infections [36]. As a result, an intensive search for new, effective antimicrobial agents is necessary, which is facilitated by exploring new resources, especially the endophytic fungi which are underexplored. Endophytic fungi are considered as promising sources for producing large variety of bioactive molecules that can protect the plant against pathogens [37,38]. Therefore, numerous attempts have been made to isolate and identify bioactive metabolites from endophytic fungi.

In the present study, L. pseudotheobromae IBRL OS-64 was subjected for preliminary antibacterial screening by agar plug method. This qualitative assay only determines the present of antibacterial substance secreted by the fungal agar plugs. The results showed that the fungus produced a broad-spectrum substance that can inhibit all the 13 test bacteria which consisted of six Gram-positive and seven Gramnegative bacteria.

To quantify the antibacterial activity from fermentative broth and fungal biomass, disc diffusion assay is the best of choice and recommended by many researchers [30]. Usually, endophytic fungi secreted their secondary metabolites extracellularly into the fermentative medium and seldom keeping them intracellularly. Since secondary metabolite substances are mean to protect the endophytic fungi from predators or pathogens, thus they are more suitable to be secreted extracellularly [11]. The results demonstrated the sizes of the inhibition zones which reflected the susceptibility level of the test bacteria.

The difference in bacteria response to the ethyl acetate extract was possibly due to the nature of the bacterial species. The extract, however, showed greater antibacterial activity against Gram-positive than Gram-negative bacteria. These results are in agreement to other researcher's findings who reported that majority of the fungal extract to be more active against Gram-positive bacteria than the Gram-negative bacterial strains $[8,39,40]$. We suspected this condition is caused by the differences in the cell envelopes composition of Gram-positive and Gram-negative bacteria which are complex dynamic structures that play a variety of protective and adaptive roles [41].

Theoretically, the cell envelope of Gram-negative bacteria are surrounded by a thin peptidoglycan cell wall, which itself is surrounded by an outer membrane containing four layer cell walls consisted of asymmetric distribution of the peptidoglycan, lipoprotein, phospholipids outer membrane, and lipopolysaccharide. These conditions make them more resistant to the penetration of antibacterial agents and consequently protect their cell membrane permeability [42]. Besides, it also hinders the movement of foreign substance into the cell. This characteristic is absent in the cell envelope of Gram-positive bacteria where there is no outer membrane but only consisted of one layer of peptidoglycan, which make them, are more susceptible to antibacterial agent [43]. Furthermore, the cell wall of Gram-positive bacteria contains lipoteichoic acids that represent unique and essential structural components to the cells and should be good drug targets to the bioactive compounds of L. pseudotheobromae IBRL OS-64.

Many studies attempted to investigate the effects of fungal extracts on different bacteria to support the antibacterial activity after exposure them to the extracts. In this study, the SEM photomicrograph's observations exhibited clearly the antibacterial effects of the ethyl acetate extract 
Table 3: Antibacterial activity of Lasiodiplodia pseudotheobromae IBRL OS-64 ethyl acetate (extracellular) and methanolic (intracellular) extracts against test microorganisms

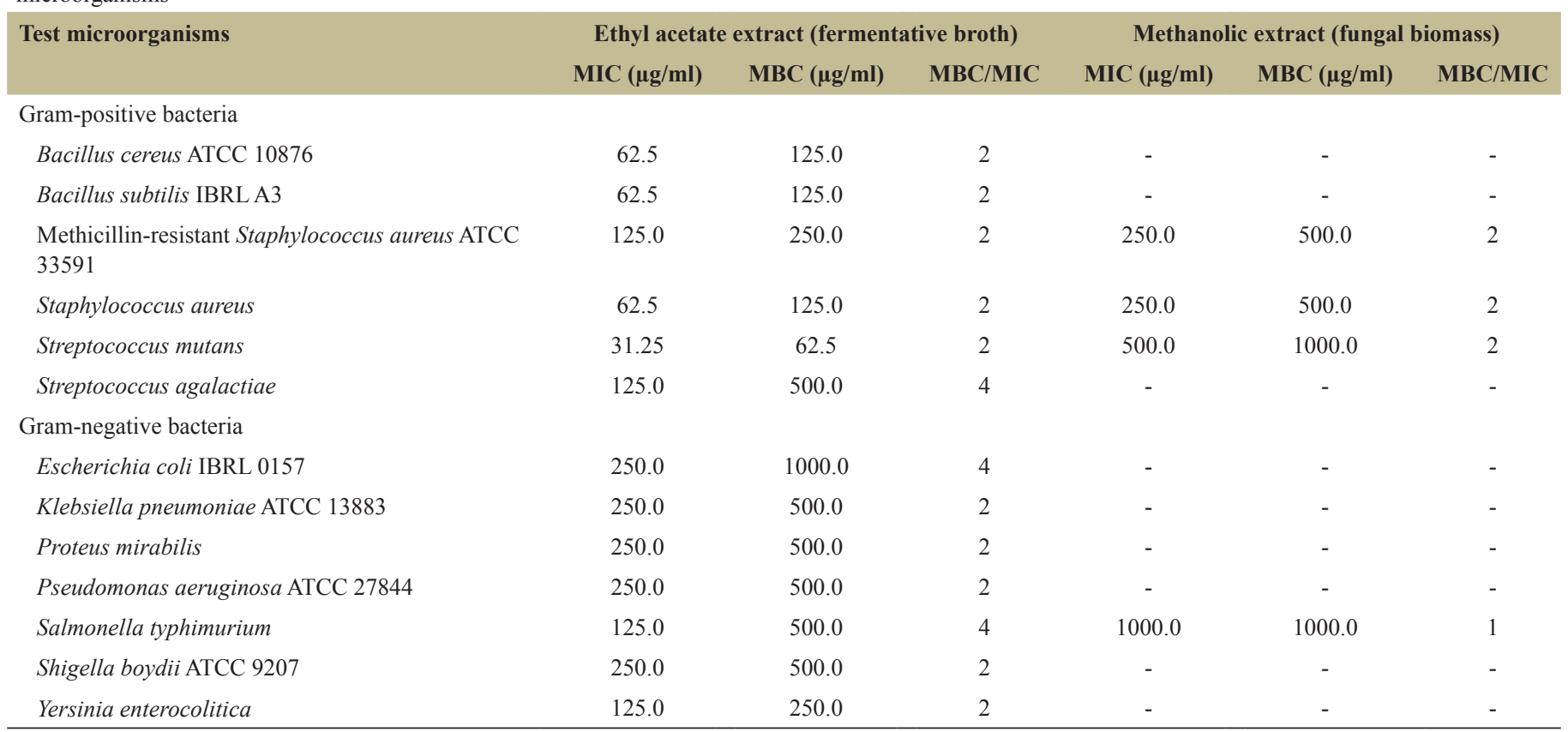

MIC: Minimal inhibitory concentration, MBC: Minimum bactericidal concentration

on both Gram-positive and Gram-negative bacterial cells. There were clear morphological changes with collapsed cells, and this could be due to the leak in the cell wall or maybe some alterations occurred in the cell membrane permeability. These findings augmented the antibacterial prospects of the ethyl acetate extract is a promising broadspectrum antibacterial agent. It was suggested that the morphological changes of the antibiotic-treated bacteria occur when the antibacterial agent attacked the cell membrane. In this case, the bioactive compound of the ethyl acetate extract of L. pseudotheobromae IBRL OS-64 that locked on the cell surface structure had permeabilized the bacterial cell membrane. Any disruption in cell wall integrity would have a great influence in bacterial growth. This prediction was coincided well with the findings of Darah et al. [44] who reported the extract of Urtica dioica exerted its inhibitory effect on the cell wall of the bacterial cells which led to the complete damage of the cells. Various studies were reported to investigate the mechanism of actions involved in bacterial killing process. The most possible mode of action involved could be the interaction of antibacterial compound with the cell membrane. As shown by the SEM micrographs where the cells became crumpled and exhibited the formation of holes, these damages may indicate the loss of cellular materials and organelles from the cell cytoplasm. These unstable and altered cells were collapsed beyond repair and finally led to cell death.

The results from this study revealed that the L. pseudotheobromae IBRL OS-64 possessed antibacterial activity against both Grampositive and Gram-negative bacteria. Wei et al. [22] also reported the ability of extract from L. pseudotheobromae F2 which residing in the flower of Illigera rhodantha showed antibacterial activity against Gram-positive (Streptococcus sp. and Peptostreptococcus sp.) and Gram-negative (Bacteroides vulgates and Veillonella parvula) bacteria. In fact, they managed to isolate six compounds, lasiodiplines A-F and found lasiodipline E demonstrated significant antibacterial activity. Therefore, the compound lasiodipline could be the bioactive compound with antibacterial activity in the L. pseudotheobromae IBRL OS-64 ethyl acetate extract.

\section{CONCLUSION}

The findings of the current study unveiled a novel, powerful, and broad-spectrum antibacterial activity of the L. pseudotheobromae IBRL OS-64 ethyl acetate extract against a number of Gram-positive and Gram-negative pathogenic bacteria by exerting bactericidal effects and causing severe morphological changes beyond repair. This study suggests that the possibly mode of action of the ethyl acetate extract against bacteria is through their cell membranes and cell walls. The isolation and identification of the bioactive compounds are in progress and will be reported elsewhere.

\section{ACKNOWLEDGEMENT}

The authors are grateful to Universiti Sains Malaysia, for awarding the RUI research grant scheme (ac: 1001/PBIOLOGI/811326) to support this study.

\section{REFERENCES}

1. D'Costa VM, King CE, Kalan L, Morar M, Sung WW, Schwarz C, et al. Antibiotic resistance is ancient. Nature 2011;477:457-61.

2. Kempf M, Rolan JM. Emergence of resistance to carbapenems in Acinetobacter baumannii in Europe: Clinical impact and therapeutic options. Int J Antimicrob Agents 2012;39:105-14.

3. Nordmann P, Poirel L, Dortet L. Rapid detection of carbapenemaseproducing Enterobacteriaceae. Emerg Infect Dis 2012;18:1503-7.

4. Kali A. Antibiotics and bioactive natural products in treatment of methicillin resistant Staphylococcus aureus: A brief review. Pharmacogn Rev 2015;9:29-34.

5. Stierle AA, Stierle DB. Bioactive secondary metabolites produced by the fungal endophytes of conifers. Nat Prod Commun 2015;10:1671-82.

6. Ryan RP, Germaine K, Franks A, Ryan DJ, Dowling DN. Bacterial endophytes: Recent developments and applications. FEMS Microbiol Lett 2008;278:1-9.

7. Gouda S, Das G, Sen SK, Shin HS, Patra JK. Endophytes: A treasure 
house of bioactive compounds of medicinal importance. Front Microbiol 2016;7:1538.

8. Darah I, Chong CL, Lim SH. Antimicrobial activity of endophytic fungi isolated from Swietenia macrophylla leaves. Nat Prod Commun 2014;9:247-50.

9. $\quad$ Tong WY, Nurul-Zaadah J, Nurhaida, Tan WN, Melati K, Latiffah Z, et al. Antimicrobial activity of Phomopsis sp. ED2 residing in medicinal plant Orthosiphon stamineus Benth. Annu Res Rev Biol 2014;4:1490-501.

10. Woei-Yenn T, Khan MA, Syuhada NA, Leong CR, Ibrahim D, Tan W. Stigmasterol: An adjuvant for beta lactam antibiotics against beta-lactamase positive clinical isolates. Steroids 2017;128:68-71.

11. Darah I, Nurhaida I, Lim SH. Anti-candidal activity of Aspergillus flavus IBRL-C8, an endophytic fungus isolated from Cassia siamea Lamk leaf. J Appl Pharm Sci 2018;8:83-7.

12. Chandra S. Endophytic fungi: Novel sources of anticancer lead molecules. Appl Microbiol Biotechnol 2012;95:47-59.

13. Wu Y, Girmay S, da Silva VM, Perry B, Hu X, Tan GT. The role of endophytic fungi in the anticancer activity of Morinda citrifolia Linn. (Noni). Evid Based Complement Alternat Med 2015;2015:393960.

14. Pretsch A, Nagl M, Schwendinger K, Kreiseder B, Wiederstein M, Pretsch D, et al. Antimicrobial and anti-inflammatory activities of endophytic fungi Talaromyces wortmannii extracts against acneinducing bacteria. PLoS One 2014;9:e97929.

15. Wellensiek BP, Ramakrishnan R, Bashyal BP, Eason Y, Gunatilaka AA, Ahmad N. Inhibition of HIV-1 replication by secondary metabolites from endophytic fungi of desert plants. Open Virol J 2013;7:72-80.

16. Prihatini AI, Tachibana S. Antioxidant compounds produced by Pseudocercospora sp. ESL 02, an endophytic fungus isolated from Elaeocarpus sylvestris. Asian Pac J Trop Biomed 2017;7:110-5.

17. Ismail AM, Cirvilleri G, Pollizzi G, Crous PW, Groenewald JZ, Lombard L. Lasiodiplodia species associated with dieback disease of mango (Mangifera indica) in Egypt. Australas Plant Pathol 2012;41:649-60.

18. Kwon JH, Choi O, Kang B, Lee Y, Park J, Kang PW, et al. Identification of Lasiodiplodia pseudotheobromae causing mango dieback in Korea. Can J Plant Patho 2017;39:241-5.

19. Castro-Medina F. First report on Lasiodiplodia pseudotheobromae causing trunk cankers in Acacia mangium in Venezuela. Plant Dis 2014;98:686.

20. Awan QN, Akgul DS. First report of Lasiodiplodia pseudotheobromae causing postharvest fruit rot of lemon in Turkey. Plant Dis 2016;100:2327.

21. Nogueira-Junior AF, Santos RF, Pagenotto AC, Sposito MB. First report of Lasiodiplodia pseudotheobromae causing fruit rot of persimmon in Brazil. New Dis Rep 2017;36:1.

22. Wei W, Jiang N, Mei YN, Chu YL, Ge HM, Song YC, et al. An antibacterial metabolite from Lasiodiplodia pseudotheobromae F2. Phytochemistry 2014;100:103-09.

23. Cimmino A, Cinelli T, Masi M, Reveglia P, da Silva MA, Mugnai L, et al. Phytotoxic lipophilic metabolites produced by grapevine strains of Lasiodiplodia species in brazil. J Agric Food Chem 2017;65:1102-7

24. Kapoor M, Saxena S. Potential xanthine oxidase inhibitory activity of endophytic Lasiodiplodia pseudotheobromae. Appl Biochem Biotechnol 2014;173:1360-74.

25. Meshram V, Saxena, S. Potential fibrinolytic activity of an endophytic Lasiodiplodia pseudotheobromae species. Biotechnol J 2016;6:114.

26. Xiaojing L, Chen G, Li Z, Zhang Y, Wang Z, Rong W, et al. Palmarumycins from the endophytic fungus Lasiodiplodia pseudotheobromae XSZ-3. Helv Chim Acta 2014;97:1269-94.

27. Qian CD, Fu YH, Jiang FS, Xu ZH, Cheng DQ, Ding B, et al. Lasiodiplodia sp. ME4-2, an endophytic fungus from the floral parts of Viscum coloratum, produces indole-3-carboxylic acid and other aromatic metabolites. BMC Microbiol 2014;2014:297-303.

28. Espinel-Ingroff A, Arthington-Skaggs B, Iqbal N, Ellis D, Pfaller MA, Messer S, et al. Multicenter evaluation of a new disk agar diffusion method for susceptibility testing of filamentous fungi with voriconazole, posaconazole, itraconazole, amphotericin B, and caspofungin. J Clin Microbiol 2007;45:1811-20.

29. Mohanraj D, Bharathi S, Radhakrishnan M, Balagurunathan R. Bioprospecting of actinobacteria from Yelagiri hills with special reference to antibacterial activity. J Chem Pharm Res 2011;3:439-46.

30. Clinical and Laboratory Standards Institute. Performance Standards for Antimicrobial Disk Susceptibility Tests. In: Approved Guideline Document M2-A9. Wayne, Pennsylvania: Clinical Laboratory and Standards Institute; 2006. p. 1-35.

31. Clinical and Laboratory Standards Institute. Performance standards for antimicrobial disk susceptibility tests. In: Approved Guideline Document M2-A11. Wayne, Pennsylvania: Clinical Laboratory and Standards Institute; 2012. p. 2-3.

32. Jorgensen JH, Ferraro MJ. Antimicrobial susceptibility testing: General principles and contemporary practices. Clin Infect Dis 1998;26:973-80.

33. Andrews JM. Determination of minimum inhibitory concentrations. J Antimicrob Chemother 2001;48 Suppl 1:5-16.

34. Tong WY, Chong CL, Darah I, Latifah Z. Enhancement of anticandidal activity of endophytic fungus Phomopsis sp. ED2, isolated from Orthosiphon stamineus Benth, by incorporation of host plant extract to culture medium. J Microbiol 2012;50:581-5.

35. Borgers M, Van de Ven MA, Van Cutsem J. Structural degeneration of Aspergillus fumigatus after exposure to saperconazole. J Med Vet Mycol 1989;27:381-9.

36. von Nussbaum F, Brands M, Hinzen B, Weigand S, Häbich D. Antibacterial natural products in medicinal chemistry-exodus or revival? Angewandte Chemie, 2006;45:5072-129.

37. Tan RX, Zou WX. Endophytes: A rich source of functional metabolites. Nat Prod Reprod 2001;18:448-59.

38. Strobel GA. Endophytes as sources of bioactive products. Microbes Infect 2003;5:535-44.

39. Khan R, Shahzad S, Choudary MI, Khan SA, Ahmad A. Communities of endophytic fungi in medicinal plant Withania somnifera. Pak J Bot 2010;42:1281-7.

40. Darah I, Chong CL, Tong WY, Lim SH. Effect of the extract of endophytic fungus, Nigrospora sphaerica CL-OP 30, against the growth of methicillin-resistant Staphylococcus aureus (MRSA) and Klebsiella pneumoniae cells. Trop J Pharm Res 2015;14:2091-7.

41. Silhavy T, Kahne D, Walker S. The bacterial cell envelope. Cold Spring Harb Perspect Biol 2010;2:414-6.

42. Goldbeck JC, Victoria FN, Savegnago AM, Jacob RG, Perin G, Lenard EJ, et al. Bioactivity and morprhological changes of bacterial cells after exposure to 3-( $p$-chlorophenyl) thio citronellal. Food Sci Technol 2014;59:813-9.

43. Kumala S, Yuliani KD, Simanjuntak P. Antimicrobial activity of secondary metabolites produced by endophytic fungi isolated from stems of jati tree (Tectona grandis L.F). Int J Pharm Sci Res 2015;6:2349-53.

44. Darah I, Chahardehi AM, Shaida FS. Effects of butanol extract of Urtica dioica on MRSA: Structure degeneration study. JABS 2013;7:39-44.

\footnotetext{
How to cite this article:

Taufiq MMJ, Darah I. Antibacterial activity of an endophytic fungus

Lasiodiplodia pseudotheobromae IBRL OS-64 residing in leaves

of a medicinal herb, Ocimum sanctum Linn. J App Biol Biotech.

2019;7(02):35-41. DOI: 10.7324/JABB.2019.70207
} 